BBA $5545 \mathrm{I}$

\title{
PURIFICATION OF CEREBROSIDE GALACTOSIDASE FROM RAT BRAIN
}

\author{
DAVID M. BOWEN* AND NORMAN S. RADIN
}

Mental Health Research Institute, University of Michigan, $4 \mathrm{nn}$ Arbor, Mich. 48 Iot (U.S.A.)

(Received December Ist, 1967)

(Revised manuscript received February 2nd, 1968)

SUMMARY

A method is described for the preparation of a $\beta$-galactosidase which acts on the brain lipid, ceramide galactoside. The enzyme is obtained from particles that sediment between I $000-13000 \times g$ from rat brains and is extracted with a $6 \%$ sodium cholate solution. The enzyme is solubilized and inactive proteins removed by digestion with pancreatic enzymes and the cholate is removed by dialysis and gel filtration. Preparative electrophoresis yields a major and a minor enzyme fraction. Chromatography of the major fraction on DEAE-Sephadex yields three fractions. The major fraction from this column can be purified further by precipitation of impurities at $\mathrm{pH}$ 5. An overall apparent increase in specific activity of over 300 -fold could be obtained, with apparent yield of $27 \%$.

While the crude enzyme was rather stable to storage, exposure to ion exchange made it unstable. It was found that $50 \%$ glycerol at $-20^{\circ}$ preserved the cerebrosidase fairly well. The purified enzyme still exhibited hydrolytic activity toward ceramide and nitrocatechol sulfate. Cerebrosidase activity was found in very young as well as in adult rats.

\section{INTRODUCTION}

We have previously reported ${ }^{\mathbf{1}}$ on a $\beta$-galactosidase from brain which was active toward brain cerebrosides (ceramide galactosides). The enzyme activity was measured by incubation with radioactive cerebroside and examination of the labeled product of hydrolysis. Because of the considerable dilution of labeled substrate by endogenous cerebroside present in brain particulate preparations, we carried out this preliminary study with the high speed supernatant fraction, which contains relatively little cerebroside. It was found that the enzyme was greatly stimulated by bile acids and could be separated partially from other $\beta$ galactosidases (detected by activity toward $o$-nitrophenyl- $\beta$-D-galactopyranoside). The enzyme could be purified several-fold, but attempts at additional purification were frustrated by a low initial specific activity

* Postdoctoral trainee, National Institute of Mental Health, Behavioral Sciences Training Branch. 
and the ease with which the enzyme became insoluble. Assuming this acid hydrolase was derived from the lysosomes, and armed with our knowledge of the properties of the enzyme, we examined the particulate fraction. This paper describes the solubilization of the particulate enzyme by means of digestion with pancreatic enzymes. The endogenous cerebroside was removed virtually completely and the specific activity increased about 300 -fold (based on the activity in the $1000-13000 \times g$ particles).

METHODS AND MATERIALS

\section{Substrates}

The earlier experiments were carried out with a mixture of beef spinal cord cerebrosides $^{1}$, and the later ones with I8: o cerebroside ${ }^{2}(N$-stearoylpsychosine). Comparisons of the two substrates showed little difference in rate of attack by different enzyme preparations. Both were labeled with ${ }^{3} \mathrm{H}$ in the 6 -position of the galactose moiety by oxidation with galactose oxidase ${ }^{3}$ and reduction with $\mathrm{NaBH}_{4}$. The chromatographically purified products were diluted about 30 -fold with the corresponding cerebrosides to yield a specific activity of $310-380$ counts/min per nmole, measured by liquid scintillation counting in a water-dioxane-naphthalene xylene-Cellosolve solution ${ }^{4}$.

The substrate emulsion was prepared before each experiment by evaporating to dryness solutions of cerebroside (I part by weight) and the detergents Triton X-Ioo* (II parts), Tween 20 (Io parts), and G-2I59 (5 parts). To the residue was added sodium taurocholate (40 parts in a I\% aqueous solution; Grade II, Sigma Chemical Co.), and the mixturc cmulsified as before ${ }^{1} . N$-stear $\left[{ }^{14} \mathrm{C}\right]$ oylsphingosine (ccramide) ${ }^{2}$ was emulsified similarly, but with only o.or3 parts of the substrate.

\section{Buffers}

Before assay all preparations were dialyzed overnight against Buffer A. It is important to remove most of the glycerol and galactose, if present, as they are inhibitory $y^{5}$.

Buffer A contained $0.05 \mathrm{M}$ Tris $-\mathrm{HCl}$, 0.0I $\mathrm{M} \mathrm{MgCl}_{2}$, and $0.008 \mathrm{M}$ mercaptoethanol (Type I, Sigma Chemical Co.). Buffer B was similar, but included I\% galactose. Buffer $\mathrm{C}$ also included $6 \%$ sodium cholate (enzyme grade, Mann Research Labs.). The $\mathrm{pH}$ of each buffer was adjusted to 7.4 , measured at room temperature. Because of the ready precipitability of cholic acid, we found it advisable to prepare Buffer C by adding the $\mathrm{MgCl}_{2}$ and sodium cholate to Tris buffer previously adjusted to $\mathrm{pH}$ 7.0.

\section{Enzyme assay}

Incubations were carried out as previously described ${ }^{1}$ in $13-\mathrm{mm}$ screw cap test tubes. The tubes were usually incubated $3 \mathrm{~h}$, after which $5 \mathrm{ml}$ of chloroform-methanol $(2: I, v / v)$ and $0 . \mathrm{Iml}$ of $0 . \mathrm{I} \%$ galactose were added. The mixture was agitated by $\mathrm{IO}$ inversions (Teflon cap liner), centrifuged, and the upper layer transferred to a tube containing I. $5 \mathrm{ml}$ of 'FoLch lower layer'b. After this washing step (shaking and centrifuging) a I.5-ml aliquot of the upper layer was evaporated to dryness in a scintilla-

* The detergents used were: Triton X-roo, octylphenoxy polyethoxy ethanol; Tween 20 , polyoxyethylene sorbitan monolaurate; G-2 I59, polyoxyethylene stearate.

Biochim. Biophys. Acta, I 52 (1968) $587-59^{8}$ 
tion vial at $50^{\circ}$ with a stream of dry air. The residue was dissolved in $0.5 \mathrm{ml}$ of water and counted in $15 \mathrm{ml}$ of scintillation solvent ${ }^{4}$.

Ceramidase activity was evaluated by incubating $N$-stearoylsphingosine under the same conditions as cerebroside, but in $20-\mathrm{mm}$ screw cap test tubes. After incubation the mixture was partitioned ${ }^{1}$, together with $0.1 \mathrm{mg}$ of stearic acid and $0.2 \mathrm{mg}$ of mixed (hydroxy and nonhydroxy) ceramides. The stearic acid in the lipid extract was isolated with a silica-gel column by elution with benzene-ether $(99: \mathrm{I}, \mathrm{v} / \mathrm{v})$ and counted by liquid scintillation.

Aryl sulfatase A activity was assayed with 2-hydroxy-5-nitrophenyl sulfate (Sigma Chemical $\mathrm{Co}_{0}$.) in $0.2 \mathrm{M}$ citrate, $\mathrm{pH} 5$ (ref. 8). Subsequent experimentation showed that the incubation conditions (citrate and Buffer A) inhibited sulfatase by at least $90 \%$ when compared to the activity obtained under the conditions of SELLINGFR ANII HIATT'.

The enzyme activity toward $o$-nitrophenyl- $\beta$-galactoside was assayed as previously described ${ }^{1}$. Repipets (L/I Industries, Berkeley, Calif.) were used to measure out the various reagents.

\section{Preparation of tissue particles}

Female rats of the Sprague-Dawley strain were anesthetized with $\mathrm{CO}_{2}$ and decapitated prior to removal of the brain. For large scale isolations, brains from mature female rats, shipped in ice, were obtained from Pel-Freez Biologicals, Rogers, Ark. The brains were homogenized and fractionated according to centrifugation schedule B of Sellinger and De Balbian Verster ${ }^{10}$. The particles sedimenting between 1000 and $13000 \times g$ ("crude mitochondrial" fraction, mitochondria plus lysosomes) were used as the starting material for purification of the enzyme.

\section{Other methods}

Sephadex G-25 columns were prepared in Buffer A, then washed with at least I. 5 bed volumes of Buffer B. Fine Sephadex was used for small scale isolations (starting with less than $20 \mathrm{~g}$ of brain), and coarse Sephadex for large scale work.

The method of Lowny et al. ${ }^{11}$ was used for protein determinations. Where samples contained Tris buffer they were dialyzed against 0.0 I M potassium phosphate $(\mathrm{pH} 7.4)$, prior to analysis.

Dialysis tubing used for enzyme isolations was first washed in water, o.oI $\mathrm{M}$ $\mathrm{NaOH}$ (30 min), water, o.or M HCl (30 min), and water (DAvid AMinorf, personal communication). Tests showed this gave an increase of $30 \%$ in activity. Enzyme solutions were concentrated by pressure ultrafiltration in Diaplex Ultrafil cells fitted with UM-I membranes (Amicon Corp., Cambridge, Mass.). Except were specified, all processing steps were carried out at $4^{\circ}$.

Thin-layer chromatography on Silica Gel G was used to estimate the amount of sodium cholate in enzyme preparations. The samples were acidified with $\mathrm{H}_{2} \mathrm{SO}_{4}$, the lipids extracted with chloroform-methanol, and the lipids of the lower layer separated with chloroform-methanol-water $(2.4: 7: \mathrm{T}, \mathrm{v} / \mathrm{v} / \mathrm{v})$. The rholic acid spot $\left(R_{F}=0.25\right)$ was detected with bromothymol blue or the more sensitive and specific phosphomolybdic acid spray ${ }^{12}$ and compared with standard spots. Alkaline bromothymol blue was used to visualize the other lipids.

All mixtures of solvents are defined on a $\mathrm{v} / \mathrm{v}$ basis. 


\section{RESULTS}

\section{Distribution of brain cerebroside galactosidase}

Table I summarizes preliminary comparison with respect to brain area, subcellular fraction, and animal age. It can be seen that the crude mitochondrial fraction is the richest source of enzyme, compared with the nuclei and debris and microsomal plus supernatant fractions. Lines I and 2 of Table I show galactosidase activity in both cerebral cortex and subcortex (the remainder of the brain minus cerebellum and olfactory bulbs). The activity in subcortex was $70 \%$ greater despite the presence in this area of a higher concentration of endogenous cerebrosides. The data in Lines 3 and 4 suggest that cortex is not much different in specific activity from whole brain. For convenience in isolation work it was decided to use the whole brain.

\section{TABLE I}

DISTRIBUTION OF CEREBROSIDE GALACTOSIDASE IN RAT BRAIN

Enzyme activity is expressed in nmoles/h/g of brain, measured with mixed radioactive cerebrosides. The ages of the mature animals were estimates. Each incubation tube contained $0.5 \mathrm{ml}$ of enzyme in $0.25 \mathrm{M}$ sucrose, o. $\mathrm{m} \mathrm{ml}$ of $\mathrm{M}$ sodium citrate $(\mathrm{pH} 4.5)$ and $0.4 \mathrm{ml}$ of substrate emulsion (o.1 $\mathrm{mg}$ labeled cerebroside, I $\mathrm{mg}$ Tween, $0.5 \mathrm{mg} \mathrm{G}-2 \mathrm{I} 59,4 \mathrm{mg}$ sodium taurocholate).

\begin{tabular}{|c|c|c|c|c|c|}
\hline \multirow{2}{*}{$\begin{array}{l}\text { Number } \\
\text { of brains } \\
\text { pooled }\end{array}$} & \multirow[t]{2}{*}{ Brain region } & \multirow[t]{2}{*}{ Rat age } & \multicolumn{3}{|c|}{ Subcellular fraction } \\
\hline & & & $\begin{array}{l}\text { Nuclei and } \\
\text { debris }\end{array}$ & $\begin{array}{l}\text { Crude mito- } \\
\text { chondria }\end{array}$ & $\begin{array}{l}\text { Microsomes plus } \\
\text { supernalant }\end{array}$ \\
\hline 5 & Cortex & I 2 days & $\mathrm{I}_{4} \cdot \mathrm{I}$ & 32.2 & 9.5 \\
\hline 5 & Subcortex & I 2 days & 20.9 & 54.0 & I 1.6 \\
\hline 8 & Cortex & 9 months & 21.6 & $47 \cdot 4$ & 21.7 \\
\hline 4 & Whole & 9 months & I 2.4 & 38.1 & 18.9 \\
\hline
\end{tabular}

Table I also shows that there is little difference in measured activity between very young and mature rats. It is likely that the concentration of the enzyme in the older rats is somewhat understated, since the dilution of the labeled substrate must be very much greater than in the younger rats ${ }^{13}$. For this reason older animals were chosen for further work.

In these and the other assays of crude enzyme, aliquot sizes were chosen to correspond to equal amounts of brain tissue.

Evidence that endogenous cerebroside does actually compete with the labeled cerebroside is furnished in the right hand column of Table II. Nonlinearity with respect to enzyme concentration (a value less than I), is consistent with such competition.

\section{Solubilization of the enzyme}

The crude mitochondrial particles were suspended in Buffer C ( $3 \mathrm{ml} / \mathrm{g}$ brain) and sonicated in an ice bath with an immersion probe for Ioo sec (Io cycles of Io sec on, Io sec off, 0.5-inch step horn. Model S-75. Heat Systems Co., Great Neck, N.Y.; power level $6,20 \mathrm{kHz}$ output, 2-3 A). At this stage and in all other experiments extraction volumes include precipitate volume. Centrifugation for I h at $55000 \times \mathrm{g}$ yielded the cholate extract, a clear tan solution. The total activity of the extract (Table II) was twice that of the crude mitochondrial fraction and the activity measure- 
TABLE II

PURIFICATION AND PROPERTIES OF CEREBROSIDE GALACTOSIDASE PREPARATIONS FROM RAT BRAIN

The data are taken from a large scale isolation starting with $250 \mathrm{~g}$ of brain, shipped on ice and utilized within $24 \mathrm{~h}$. Enzyme units are nmoles of $18: 0$ cerebroside hydrolyzed per h. Linearity refers to the ratio of specific activities observed with enzyme derived from soo $\mathrm{mg}$ of brain and $50 \mathrm{mg}$ of brain. The activities reported are based on the data from $50 \mathrm{mg}$ equivalents. In the case of Fraction VII, because of the relatively low yield of enzyme in the ion-exchange step, somewhat larger equivalents were used (see ref. 5). The crude mitochondrial particles were assayed under conditions similar to Fractions II and III, that is, after suspension in $6 \%$ cholate and dialysis for $36 \mathrm{~h}$ against Buffer $\mathrm{A}$.

\begin{tabular}{|c|c|c|c|c|c|c|}
\hline Fraction & $\begin{array}{l}\text { Total } \\
\text { protein } \\
\text { (mg/g } \\
\text { brain) }\end{array}$ & $\begin{array}{l}\text { Total } \\
\text { activity } \\
\text { (units/g } \\
\text { brain) }\end{array}$ & $\begin{array}{l}\text { Specific } \\
\text { activity } \\
\text { (units/mg } \\
\text { protein) }\end{array}$ & $\begin{array}{l}\text { Purifica- } \\
\text { tion } \\
\text { factor }\end{array}$ & $\begin{array}{l}\text { Recov- } \\
\text { ery } \\
(\overline{\%} \%)\end{array}$ & $\begin{array}{l}\text { Linear- } \\
\text { ity }\end{array}$ \\
\hline I. Crude mitochondrial particles & $35 \cdot 4$ & $2 I$ & 0.58 & I & 100 & $0.6 \mathrm{I}$ \\
\hline II. Cholate extract & 24.7 & 37 & $\mathbf{I} .5$ & 2.6 & I 8 I & $0.8 \mathbf{I}$ \\
\hline III. Lipase-treated extract & $2.5^{*}$ & 52 & $21^{*}$ & $37^{*}$ & 257 & 0.86 \\
\hline IV. Sephadex G-25 supernatant & I.9 & 48 & 25 & 42 & 230 & I.OO \\
\hline V. Conc. enzyme & 0.95 & 38 & 40 & 68 & 183 & I.07 \\
\hline $\begin{array}{l}\text { VI. Combined supernatant frac- } \\
\text { tions after electrophoresis } \\
\text { VII. Fraction from DEAE- }\end{array}$ & 0.30 & 20 & 67 & I I 5 & 98 & I.05 \\
\hline Sephadex & 0.037 & 5.9 & 159 & 275 & 29 & I.0O \\
\hline VIII. $\mathrm{pH}-5$ supernatant & 0.030 & $5 \cdot 5$ & 182 & $3 \mathrm{I}_{4}$ & 27 & \\
\hline
\end{tabular}

* Protein determinations were not made in this particular run but were estimated on the basis of experience with other runs.

ments were more linear with respect to enzyme concentration. The improvement in observed activity may be due to removal of part of the endogenous cerebroside.

To portions of cholate extract was added a crude pancreatic lipase preparation ('pork lipase powder', No. 4633, Mann Research Labs., New York, N.Y.; 8 mg/g brain). Because of the partial insolubility of the lipase, the portions were sonicated briefly in an ultrasonic bath of the type used for cleaning, then transferred to individual dialysis bags. The suspensions were dialyzed overnight against two changes of Buffer A ( $70 \mathrm{ml} / \mathrm{g}$ brain). The bags were supported horizontally and shaken with a horizontal gyratory agitator to keep the particles in suspension. To complete the lipase action the mixture was incubated at $37^{\circ}$ for $I h$, and the residual insoluble matter was removed by centrifugation at $55000 \times g$ for $\mathrm{I} h$.

Analysis of this extract showed that at least $90 \%$ of the protein in the original cholate extract had been removed, evidently due to proteolytic activity in the pancreatic preparation.

Fig. I shows the effect of removing cholate from the cholate extract by the dialysis-incubation procedure in the absence of lipase (Tube 2). The clear solution became turbid during dialysis, and even more so during the incubation. Tube 3 shows the effectiveness of the lipase in preventing this effect; only minor amounts of insoluble material were visible. The lipase suspension itself, as the result of the same treatment, became quite clear (T11be r); only about $0.35 \mathrm{mg}$ of protein was left out of an $8-\mathrm{mg}$ portion of powder and practically all of this was soluble.

Table II shows that the lipase treatment raised the total observed activity and improved the linearity still further. Both effects can again be explained as due to removal of endogenous cerebroside. Cerebroside was indeed detected in the insoluble 
material remaining after solubilization with lipase. It was identified by thin-layer chromatography of the lipids from this material.

The lipase step raised the specific activity of the enzyme about I4-fold.

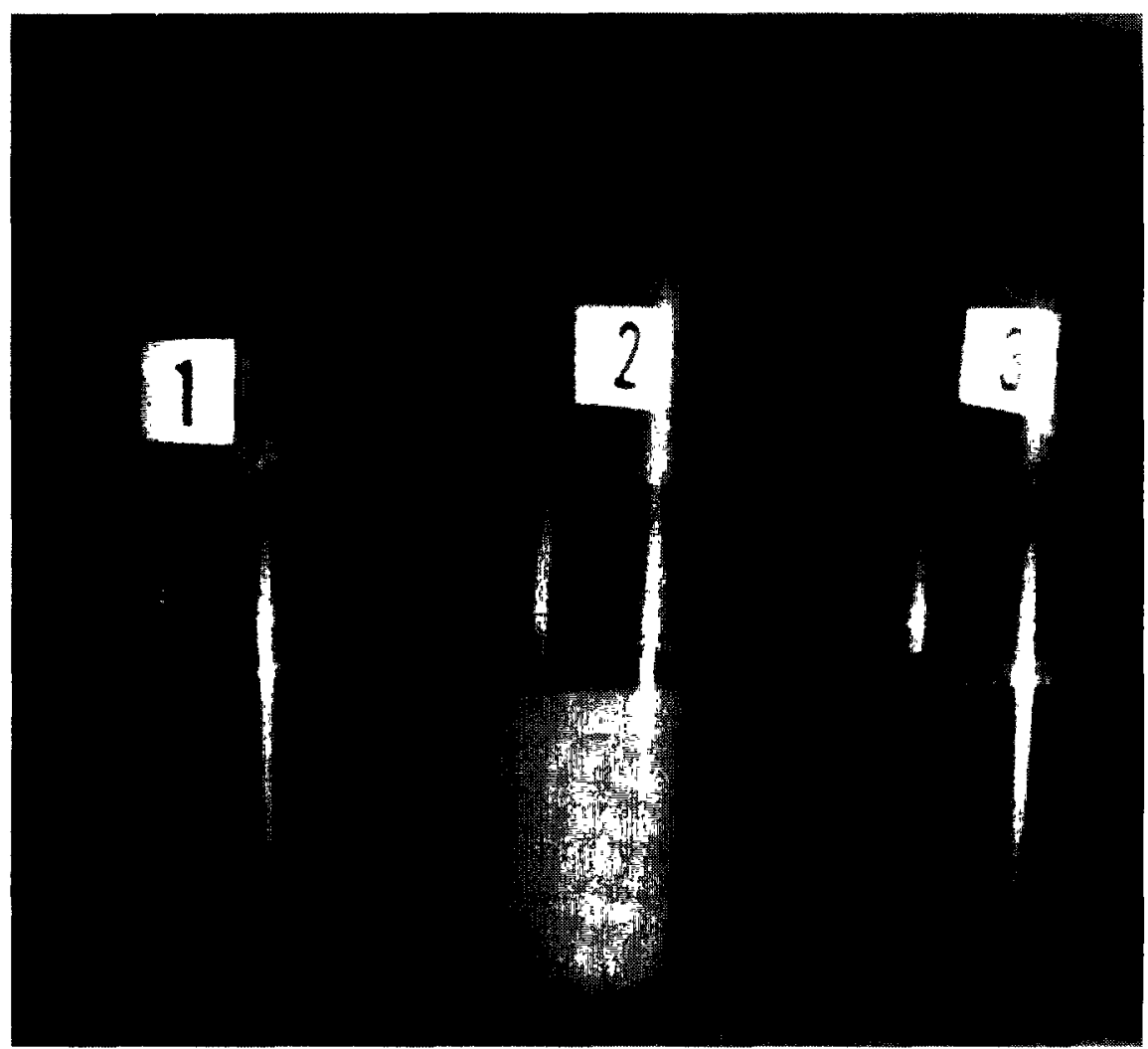

Fig. I. Effects of cholate removal and of treatment with pancreatic enzymes on solubility of proteins in cholate extract of brain particles. Tube I contains pancreatic lipase that had been dialyzed overnight and incubated $\mathrm{I}$ h at $37^{\circ}$. Tube 2 contains the extract of brain particles made with $6 \%$ cholate, dialyzed and incubated as above. Tube 3 contains both cholate extract and Iipase, dialyzed and incubated.

\section{Purification of the cerebroside galactosidase}

The dialysis during lipase treatment brought the cholate concentration down from 6 to $3 \%$. We found that cholate at this concentration interfered with ionexchange chromatography and, after some experimentation, found that the cholate could be removed nearly completely by gel filtration. The enzyme solution was made up to $\mathrm{I}_{\%}$ in galactose and applied to a column of Sephadex G-25 in Buffer B ( $\mathrm{I}$ ml enzyme per $5 \mathrm{ml}$ bed volume). About $90 \%$ of the enzyme activity appeared on elution with the same buffer in approximately the I.O-I.5 void volume of eluate. This fraction was very turbid. The following eluates were decreasingly turbid and contained increasing concentration of cholate, which was estimated by acidifying portions of eluate and observing the amount of characteristic precipitate. Additional galactosidase activity was present in the fraction immediately following the very turbid fraction, but it was evidently slightly contaminated with cholate. 
The insoluble material in the initial active eluate was removed by centrifugation $(\mathrm{I} \mathrm{h}$ at $55000 \times \mathrm{g}$ ) and found to contain only trace amounts of enzyme activity. Because this inactive material was readily resolubilized by the cholate present in the later eluates, the second active eluate fraction was centrifuged separately and the two supernatant liquids were combincd. The data in Table II show that this step achieved a slight increase in specific activity. The enzyme at this and subsequent stages exhibited good linearity with respect to enzyme concentration.

The enzyme was now concentrated up to 200 -fold by ultrafiltration and glycerol was added to make its concentration $15 \%(\mathrm{w} / \mathrm{v})$. This was dialyzed overnight against a Tris- $\mathrm{HCl}$ buffer (o.0I $\mathrm{M}, \mathrm{pH} 7.4$ ) containing $0.002 \mathrm{M} \mathrm{MgCl}_{2}$, $0.008 \mathrm{M}$ mercaptoethanol, $\mathrm{I}^{\circ}$ o galactose, and $\mathrm{I} 5 \%$ glycerol. A small amount of precipitate was removed by centrifugation $(80000 \times g$ for $I .5 \mathrm{~h}$ ) but some floating material was retained. This preparation (Fraction V, Table II) was somewhat increased in specific activity, despite some loss of total activity.

Further purification was achieved with a density gradient electrophoresis column (LKB Instruments, Rockville, Md., 3-cm inside dianneter). The lower part of the column was filled with the same buffer solution as above, but with a higher glycerol concentration $\left(50^{\circ} \%\right)$. Above this were $280 \mathrm{ml}$ of the same buffer containing a 5 to $20 \%$ linear glycerol gradient. A sample of Fraction- $V$ enzyme derived from $\mathbf{I} 8 \mathrm{og}$ of brain was then layered between the cushion layer and bottom of the gradient. Although the glycerol concentration in the sample was only $15 \%$, the protein increased the solution density so that it sank in $20^{\circ}$ o glycerol.

The anode (top) and the cathode vessels were filled with the same buffer but without glycerol. The column was cooled with water at $8-10^{\circ}$ while a current of $\mathrm{r} 3$ $\mathrm{mA}$ at $220 \mathrm{~V}$ was applied for $\mathrm{I} 9 \mathrm{~h}$. The column contents were then collected in $\mathrm{I} 0-\mathrm{ml}$ aliquots through the outlet at the top of the column.

The sample became turbid upon entering the column, and two additional turbid zones moved upward during the electrophoretic separation. The top band (eluting as Fractions $8-\mathrm{IO}$ ) was actually a pair of very close bands; the middle band showed visible clumps and trailed downward (Fractions II-20); the band at the origin (Fractions $27-30$ ) was tan and turbid. The enzyme activity was spread over a fairly wide range, with $8 \%$ of the recovered activity in Fractions $8-12,69 \%$ in $13-26$, and $23 \%$ in the starting band $(27-30)$. Overall recovery in these three groups was $108_{0}^{\circ}$.

Fractions $13-26$ were pooled and centrifuged at $55000 \times g$ for $2 \mathrm{~h}$. The pellet contained only $2 \%$ of lle activity while the recovery in the clear supernatant solution was $72 \%$ of that initially in the middle band. This preparation (Fraction VI, Table II) represented a purification of II6-fold and a recovery of $98^{\circ}$, based on the crude mitochondrial particles. The electrophoresis step achieved an increase in specific activity of $68^{\circ} ;$.

A similar electrophoretic run was made with a much smaller sample (derived from $26 \mathrm{~g}$ of brain, concentrated only 25 times after the Sephadex step, dialyzed against $20 \%$ glycerol buffer, and added in $5 \mathrm{ml}$ ). The lowest turbid band was not visible and the other bands were much fainter. Fig. 2 shows the results of enzyme and protein assays on some of the fractions. The major part of the activity occurred in a relatively sharp peak, with a secondary peak at the origin. The activity in the latter fraction, which exhibited the highest protein concenlration, was $24^{\circ} ;$ of the recovered activity, as in the large scale run. Fractions $\mathrm{I}-20$ contained no activity, 
while the pooled Fractions $23-27$ contained $74 \%$ of the activity with a specific activity of 79 nmoles per h per mg protein.

Fraction VI was dialyzed against the same buffer system used for electrophoresis ( $15 \%$ glycerol) and chromatographed on a column containing DEAE-Sephadex A-25 (see Fig. 3). Increasing concentrations of $\mathrm{NaCl}$ were used in the eluent and as the fractions were obtained from the column they were promptly mixed with an equal volume of glycerol and stored at $-20^{\circ}$. Fig. 3 shows that the galactosidase separated into three fractions: $35^{-1} 30 \mathrm{ml}$; I30-I $80 \mathrm{ml}$; $180-230 \mathrm{ml}$. (Note that the
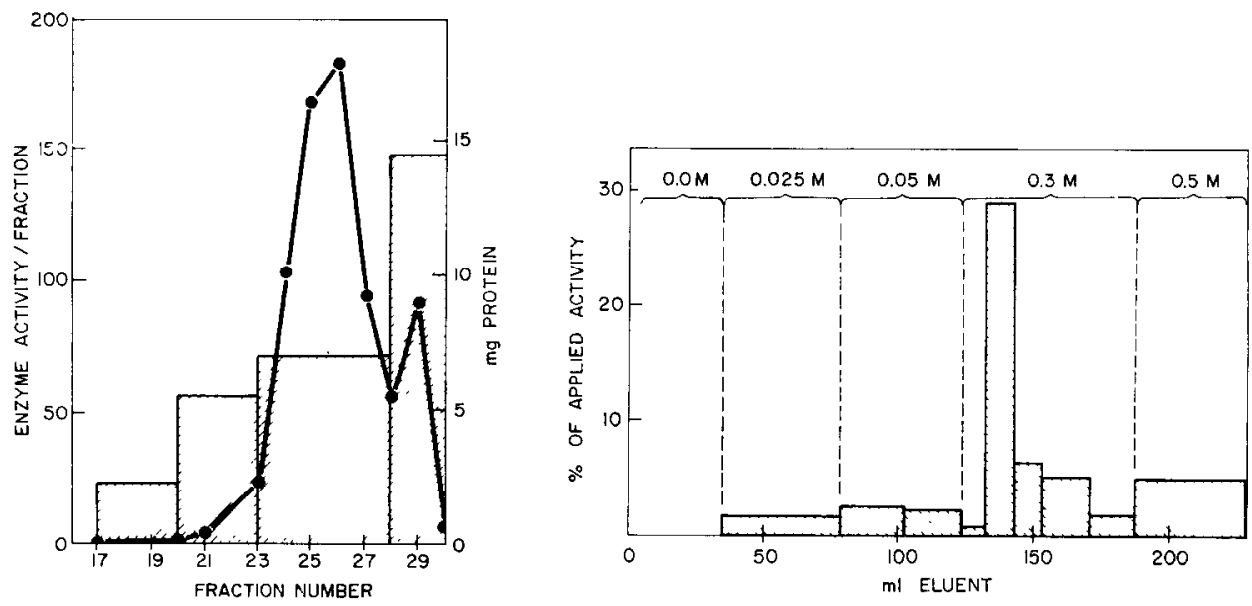

Fig. 2. Electrophoresis of cerebroside galactosidase. A current of $9.7 \mathrm{~mA}$ at $300 \mathrm{~V}$ was applied for I $7.5 \mathrm{~h}$. Details of electrophoresis and of sample size are given in text. $\bullet$, nmoles 18 :o cerebroside hydrolyzed per $\mathrm{h}$ per fraction; crosshatched areas are $\mathrm{mg}$ protein per fraction.

Fig. 3. Ion-exchange chromatography of enzyme isolated by electrophoresis. The results were obtained with $150 \mathrm{ml}$ of Fraction V/I (Table II), equivalent to $\mathbf{I} 70 \mathrm{~g}$ of brain. The column was DEAE-Sephadex A-25 (I.56 cm $\times$ I $2 \mathrm{~cm}$ ), equilibrated and eluted with o.o I M Tris-- $\mathrm{HCl}$ (pH 7.4 ) containing $0.002 \mathrm{M} \mathrm{MgCl}$, $0.008 \mathrm{M}$ mercaptoethanol, $1 \%$ galactose, and increasing concentrations of $\mathrm{NaCl}$ (see top of figure).

total activity in each crosshatched area of the figure is proportional to the height of the bar, not its area.) The portion eluting between $\mathrm{I} 33$ and $\mathrm{I} 44 \mathrm{ml}$ (Fraction VII, Table II) represented an overall 276 fold purification and $29 \%$ rccovcry. The recovery in all three fractions (assayed when 3 -days old) was $55 \%$. In another experiment fractions were assayed immediately and the recovery was higher $(74 \%)$.

Analysis of the lipids in $80 \mu \mathrm{g}$ of Fraction VII, made on a chloroform-methanol extract by means of thin-layer chromatography, revealed the presence of small amounts of cholesterol and cholate. In addition, traces of cerebroside and other lipids could be seen on the plate. The intact enzyme also showed the presence of arylsulfatase and ceramidase.

Fraction VII could be purified further by dialysis (0.025 M Tris ( $\mathrm{pH} 7.4), 0.004 \mathrm{M}$ mercaptoethanol, $0.005 \mathrm{M} \mathrm{MgCl}_{2}, \mathrm{I}_{\%} \%$ galactose) and addition of sufficient I $\mathrm{M}$ sodium citrate buffer $(\mathrm{pH} 5.0)$ to bring the mixture to $\mathrm{pH}$ 5.0. A precipitate that formed during $\mathrm{I} h$ of stirring was removed by centrifugation at roo ooo $\times g$ for $\mathrm{I} h$. The supernatant fraction (Fraction VIII, Table II) was immediately dialyzed against Buffer A. 
It contained $9 \mathrm{r} \%$ of the activity while the precipitate contained less than $5 \%$. This step resulted in an overall $3 \mathrm{I}_{4}$-fold purification with recovery of $27 \%$. While the acid precipitation did not result in much improvement in purity, it removed nearly half of the activity toward ceramide glucoside ${ }^{5}$. The exact degree of overall purification of the cerebrosidase is uncertain because of our inability to correct for the diluting effect of endogenous cerebroside in the crude preparations on the radioactive cerebroside. Determination of the purification achieved by starting with a centrifugally purified fraction (the crude lysosomes) was not even attempted.

\section{Problems of solubilization}

Both Triton X-Ioo and sodium cholate solubilized part of the cerebroside from the crude mitochondrial fraction. Experiments with the enzyme from the brain supernatant fraction ${ }^{5}$ showed that a high concentration $(6 \%)$ of cholate was needed to keep the enzyme deaggregated. The enzyme readily reaggregated on removal of the cholate by dialysis, a phenomenon noted by other investigators working with membranebound proteins. Addition of $1.5 \%$ Triton prior to dialysis reduced the amount of precipitation, but even the remaining 'soluble' enzyme must have been somewhat aggregated for only half could be adsorbed to DEAE-Sephadex. Similar reaggregation seemed to occur on treating the cholate extract with $\left(\mathrm{NH}_{4}\right)_{2} \mathrm{SO}_{4}$ or butanol ${ }^{14}$.

Since the cholate extract was quite rich in brain lipids, we thought these might contribute to the reaggregation following removal of the cholate. Crude pancreatic lipase had been used to solubilize enzymes of other tissues ${ }^{15,16}$ and we thought it might hydrolyze the aggregating components of the brain extract.

To tcst this hypothesis, wc incubated a cholate extract with lipase as described in the purification procedure. The soluble $(\mathrm{S})$ and insoluble $(\mathrm{P})$ portions thus obtained were processed further: $\mathrm{S}$ was dialyzed for $\mathrm{I} 8 \mathrm{~h}$ against buffer $\mathrm{A}$, yielding a precipitate $\left(S_{p}\right)$ and clear supernatant $\left(S_{s}\right)$ on centrifugation. $P$ was extracted for $18 \mathrm{~h}$ with Buffer A containing $0.2 \%$ Triton $\left(2.6 \mathrm{ml} / \mathrm{g}\right.$ of brain), and the soluble $\left(\mathrm{P}_{\mathrm{s}}\right)$ and insoluble $\left(\mathrm{P}_{\mathrm{p}}\right)$ portions isolated by centrifugation.

Table III, Line I shows that dialysis of the cholate extract without treatment with lipase results in considerable precipitation of activity $\left(\mathrm{P}_{\mathbf{s}}+\mathrm{P}_{\mathrm{p}}\right)$ and a second dialysis precipitates more activity $\left(S_{p}\right)$. Lines 2 and 3 show that the use of lipase doubles the amount of soluble activity $\left(\mathrm{S}_{\mathrm{s}}\right)$ and reduces the amount precipitating on further dialysis $\left(\mathrm{S}_{\mathrm{p}}\right)$. Much of the brain protein, especially in the insoluble portion $\left(\mathrm{P}_{\mathrm{p}}\right)$, was digested by this treaturent.

Lines 3,4 and 5 show that more intense lipase treatment produces only a slowly decreasing yield of soluble enzyme $\left(S_{s}\right)$ but has little effect on the insoluble portion $\left(\mathrm{P}_{\mathrm{s}}+\mathrm{P}_{\mathrm{p}}\right)$. It would appear that the galactosidase is relatively resistant to the proteolytic activity in the pancreatic preparation.

\section{Factors affecting stability of galactosidase}

It was noted that the enzyme at Stages IV and $V$ was quite stable to storage at $4^{\circ}$, but purification by ion exchange rendered it unstable. Tests were therefore made of various substances for their potentially stabilizing effect, using a cerebrosidase purified with DEAE-Sephadex but not by electrophoresis. The enzyme was stored in Buffer A at $4^{\circ}$ and at $-20^{\circ}$ for $x_{4}$ days, then dialyzed overnight against the same buffer to remove the added materials before assay. Glycerol was tested because it 
TABLE III

EFFECT OF PANCREATIC ENZYMES ON THE SOLUBILITY OF RAT BRAIN CEREBROSIDE GALACTOSIDASE Crude mitochondrial particles were prepared from whole brains of 7 -month-old rats. The substrate emulsion was prepared without Triton. This detergent was added to incubation tubes containing $\mathrm{S}_{\mathrm{s}}, \mathrm{S}_{\mathrm{p}}$ and $\mathrm{P}_{\mathrm{p}}$ so that the final concentration of Triton in all tubes was as usual. In Expt. B, an aduitional $8 \mathrm{mg} / \mathrm{g}$ brain of pancreatic lipase was added after each hour of incubation at $37{ }^{\circ}$. Enzyme activity units are in nmoles mixed cerebroside hydrolyzed/h/g of brain. Protein contents, $\mathrm{mg} / \mathrm{g}$ brain, are given in parentheses next to enzyme activities in Expt. A. Preparation of the soluble (S) and precipitated (P) enzyme fractions is described in the text.

\begin{tabular}{|c|c|c|c|c|c|c|}
\hline \multirow[t]{2}{*}{ Expt. No. } & \multicolumn{2}{|c|}{ Conditions } & \multicolumn{3}{|c|}{ Activity in enzyme fractions } & \multirow[b]{2}{*}{$\begin{array}{l}P_{p} \\
\text { (units) }\end{array}$} \\
\hline & $\begin{array}{l}\text { Lipase } \\
\text { (mg/g) }\end{array}$ & $\begin{array}{l}\text { Incubation time } \\
\text { (h) }\end{array}$ & $\begin{array}{l}S_{s} \\
\text { (units) }\end{array}$ & $\begin{array}{l}S_{p} \\
\text { (units) }\end{array}$ & $\begin{array}{l}P_{s} \\
\text { (units) }\end{array}$ & \\
\hline $\mathrm{I}-\mathrm{A}$ & none & I & $26(4.3)$ & $6.1(\mathrm{I} .0)$ & $1.6(0.4)$ & $20.2(14.8)$ \\
\hline $2-A$ & 8 & $\mathbf{I}$ & $52(1.4)$ & I.I (O.J) & $8.2(0.2)$ & I6 (o.8) \\
\hline $3-\mathrm{B}$ & 8 & I & 59 & I.7 & 9.2 & I 2 \\
\hline $4-B$ & 16 & 2 & 52 & 0.8 & 8.4 & I I \\
\hline $5-\mathrm{B}$ & 24 & 3 & 47 & 0.3 & 10.6 & $I_{4}$ \\
\hline
\end{tabular}

stabilizes the galactosidase of Escherichia coli17 and prevents the cold-induced aggregation of a steroid dehydrogenase ${ }^{18}$. Galactose was tested because it is a product of the enzyme's action. Galactonolactone was tried because it is a specific inhibitor of galactosidases $^{\mathbf{1 9}}$ and of cerebroside galactosidase ${ }^{\mathbf{5}}$, while fructose diphosphate was tried because it is an activator of an enzyme involved in lipid metabolism ${ }^{20}$.

The enzyme stored without additives lost $95 \%$ of its activity at both temperatures. Galactonolactone $(0.8 \mathrm{mM})$, fructose diphosphate $(25 \mathrm{mM})$, and glycerol $\left(20^{\circ} \%\right)$ showed little effect, but $\mathrm{I} \%$ galactose showed partial protection at $-20^{\circ}$ (79\% loss). Bovine serum albumin, o.I \% , produced $14 \%$ stimulation on addition to fresh enzyme, and appreciable protection on storage. The activity lost at $4^{\circ}$ was $47_{\%}^{\circ}$; at $-20^{\circ}, 77 \%$.

In another experiment, $I_{\%}^{\circ}$ galactose was found to show protective action at $4^{\circ}$ for a few days. Since $20 \%$ glycerol froze at $-20^{\circ}$, and since freezing reduced the protective action of albumin, we tried a higher concentration of glycerol, $50 \%$, augmented with $\mathrm{I}_{\%}^{\circ}$ galactose. This mixture did not freeze at $-20^{\circ}$ and was found to give very good protection for several months.

The effectiveness of $\mathrm{Mg}^{2+}$ and mercaptoethanol, which were present in all buffers, was not checked with this enzyme but they have been shown to stabilize and stimulate galactosidase from $E$. coli ${ }^{18,21}$. The cerebrosidase from brain homogenate supernatant was found to be severely inhibited by mercuribenzoate but unaffected by mercaptoethanol ${ }^{1}$.

\section{Separation from other acid hydrolases}

We assessed the effectiveness of several purification methods with respect to the removal of hydrolases acting on ceramide, nitrophenyl galactoside, and nitrocatechol sulfate. This sulfatase assay was used because cerebroside sulfatase is also active toward the artificial substrate ${ }^{22}$.

It was found that the lipase solubilization step preserved the sulfatase and ceramidase about as well as the cerebrosidase, while the protein and nitrophenyl galactosidase were reduced about $90 \%$. This is consistent with the view that the sulfatase is primarily a sphingolipid hydrolase. A small portion of the ceramidase $(6 \%)$ and sulfatase $(\mathrm{I} \%$ ) in Fraction III could be shown to have originated in the pancreatic lipase. (Only a trace of cerebroside galactosidase was found in the lipase.) 
Purification of the soluble enzymes by DEAE-Sephadex chromatography, using a linear $\mathrm{NaCl}$ gradient (Fig. 4), revealed that ceramidase is eluted with the descending arm of the cerebrosidase activity, and that sulfatase follows. Ceramidase,

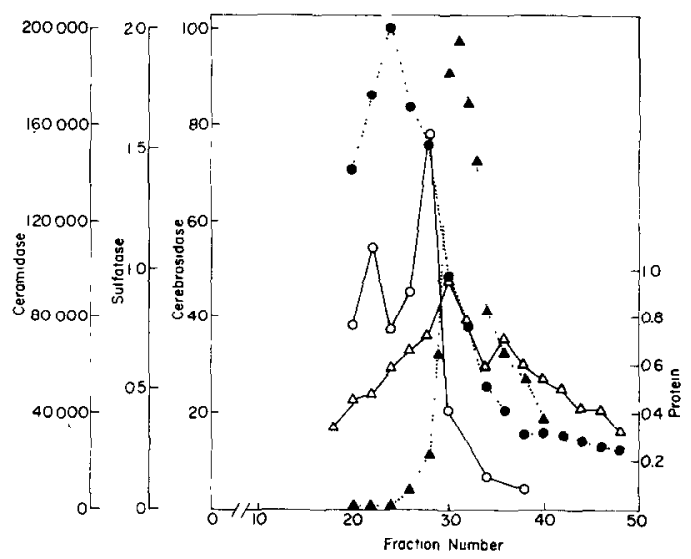

Fig. 4. Ion-exchange chromatography of enzymes solubilized with pancreatic enzymes. The starting sample was equivalent to Fraction IV, Table II. The enzymes (from $\mathrm{ro}_{4} \mathrm{~g}$ brain in $4 \mathrm{I} \mathrm{ml}$ of Buffer B) were applied to a column of DEAL-Sephadex, $(2.9 \mathrm{~cm} \times 38.5 \mathrm{~cm})$. After passage of $375 \mathrm{ml}$ of Buffer $\mathrm{B}$, a NaCl linear gradient was begun, using $1200 \mathrm{ml}$ of buffer in each chamber, with $0.3 \mathrm{M}$ $\mathrm{NaCl}$ in the second one. The volume of each fraction collected was $39 \mathrm{ml}$. nmoles r $8: 0$ cerebroside hydrolyzed per $h$ per fraction; $c$, counts/min stearic acid released per fraction in a $4 \mathrm{~h}$ incubation; $\boldsymbol{A}, \mu$ moles nitrocatechol sulfate hydrolyzed per $h$ per fraction, incubation time 105 $\min ; \Delta, \mathrm{mg}$ protein per fraction.

like cerebrosidase, was not precipitated when the solubilized enzyme (Fraction III) was adjusted to $\mathrm{pH} 5$ nor could the two be separated by density-gradient electrophoresis. Both resisted the effect of prolonged treatment with pancreactic enzymes.

DISCUSSION

Our finding (Table I) that the cerebroside hydrolase occurs in higher concenIration in brain subcortex than in cerebral cortex is of interest since the subcortex is enriched in cerebrosides. This association of the enzyme with its substrate suggests that cerebrosides are the true natural substrate for our galactosidase. 'Total galactosidase', as measured by cleavage of o-nitrophenyl galactoside, also showed a higher concentration (by $75 \%$ ) in subcortex crude mitochondrial particles.

The question must be considered whether treatment with pancreatic enzymes degraded the cerebrosidase. Longer treatment with the hydrolases (Table III) was found to have little effect on the cerebrosidase activity. Thus, if there is degradation during the first stages of lipase treatment, one might conclude that there is a resistant 'core' in the enzyme. A number of proteins are known to be completely resistant to trypsin action, and several glycosidases have been solubilized by trypsin or papain (refs. 23-25). Moreover, a hydrolase acting on a lipid (cholesterol esters) has been shown to be specifically protected against proteolytic inactivation by bile salts ${ }^{26}$. 


\section{ACKNOWLEDGEMENTS}

This investigation was supported in part by Research Grant NB-03r92 from the National Institutes of Health, U.S. Public Health Service, and PHS Training Grant No. 74I 7 from the National Institute of Mental Health. The gift of the detergent, G-2I59, from Atlas Chemical Industries, Inc., Wilmington, Delaware, is gratefully acknowledged. We were aided by the excellent assistance of Mrs. DeLores BLACKMER.

\section{REFERENCES}

I A. K, HajRa, D. M. Bowen, Y. Kirshimoto and N. S. Radin, J. Lipid Res., 7 (1966) 379.

2 K. C. Kopaczyk and N. S. Radin, J. Lipid Res., 6 (1965) I 4 o.

3 B. W. Agranoff, N. S. Radin and W. Suomi, Biochim. Biophys. Acta, 57 (Ig6z) 194.

4 G. A. Bruno and J. E. Christian, Anal. Chem., 33 (Ig6I) I2I6.

5 D. M. Bowen and N. S. Radr, Biochim. Biophys. Acta, I52 (1968) 599.

6 J. Folch, M. Lees AND G. H. Slonne-Stanley, J. Biol. Chem, 226 (1957) 497.

7 A. B. Rox, Biochem. J., 53 (1953) 12.

8 W. Bleszynski, Enzymologia, 3 I (1967) 169.

9 O. Z. Sellinger and R. A. Hiatt, Brain Res., 7 (1968) igl.

io O. Z. Sellinger and F. De Balbian Verster, J. Biol. Chem., 237 (1962) 2836.

11 O. H. Lowky, N. J. Rosebrovgh, A. L. Farr ayd R. J. Randall, J, Biol. Chem., 193 (195I) 265 .

i 2 H. Ganshirt, F. W. Koss and K. Morianz, Avzmeimittel-Forsch., Io (196o) 943.

I 3 Y. Kishimoto, W. E. Davies and N. S. Radin, J. Lipid Res., 6 (1965) 532.

I 4 R. Gitzelmann, E. A. Davidson and J. Osinchak, Biochim. Biophys. Acta, 85 (rg64) 69.

I5 E. G. Ball, J. Biol. Chem., I28 (r939) 5 I.

I6 J. C. MathIES, Biochim. Biophys. Acta, 7 (195I) 387.

i 7 F. J. Reithel, R. M. Newton and M. EAgleson, Nature, 210 (1966) I 26.5.

Is J. Jarabak, A. E. Seeds, Jr. And P. Talalay, Biochemistry, 5 (r966) I 269.

I9 J. Conchie, J. Findlay And G. A. Levvy, Biochem. $J$., 7 r (I959) 318.

zo S. J. Wakn, J. Goldman, I. P. Williamson and R. E. Toomey, Proc. Natl. Acad. Sci. U.S., $55(1966) 880$.

21 G. R. Craven, E. Steers, Jr. And C. B. Anfinsen, J. Biol. Chem., 2 qa (1965) 2468.

22 E. Menl and H. Jatzkewitz, $Z$. Physiol. Chem., 339 (1964) 260.

23 S. Auricchio, A. Dahlovist and G. Semenza, Biochim. Biophys. Acta, 73 (1963) 582.

$2+$ A. Dahlovist, Biochem. J., 86 (1963) 72.

25 B. Borgström and A. Dahlquist, Acta Chem. Scand., I2 (1958) 1997.

26 G. V. Vahotny, H. Kothari and C. R. Treadwell, Arch. Biochem. Biophys., I 2 r (1967) 242.

Biochim. Biophy's, Acfa, $152(1968) 587-598$ 